\title{
Immunochemical Studies of Human Prolidase with Monoclonal and Polyclonal Antibodies: Absence of the Subunit of Prolidase in Erythrocytes from a Patient with Prolidase Deficiency
}

\author{
FUMIO ENDO, KUNIHIKO MOTOHARA. YASUHIRO INDO. AND ICHIRO MATSUDA
}

Department of Pediatrics, Kumamoto University Medical School Honjo 1-1-1. Kumamoto 860). Japan

\begin{abstract}
Prolidase was highly purified from human liver and erythrocytes. $\mathrm{NaDodSO}_{4} /$ acrylamide gel electrophoresis revealed that these preparations contained a major protein with $\mathrm{MW}=\mathbf{5 6 , 0 0 0}$. The mass of prolidase was estimated on gel filtration to be $\mathrm{MW}=\mathbf{9 7 , 0 0 0}$, for both enzyme preparations. A monoclonal antibody was raised against the liver enzyme and a specific antiserum against the erythrocyte enzyme. The monoclonal antibody (EP-2) recognized prolidase from erythrocytes and liver, in equal proportions. The antiserum also recognized the enzyme from erythrocytes and liver. Immunoprecipitation studies with these antibodies suggested only a single species of prolidase in erythrocytes and liver. Using an immobilized monoclonal antibody (EP-2) as an immunoadsorbent, prolidase was partially purified from crude extracts, and the protein of the partially purified enzyme was identified by immunoblotting using antiserum. $A$ protein band with a MW $=56,000$ was demonstrated specifically when crude extracts from the liver and erythrocytes were examined using $\mathrm{NaDodSO}_{4} /$ acrylamide gel electrophoresis. The subunit protein was absent in erythrocytes from a patient with prolidase deficiency. We propose that the absence of the subunit is one cause of the prolidase deficiency. (Pediatr Res 22: 627-633, 1987)
\end{abstract}

\section{Abbreviations}

IPIC, high performance liquid chromatography NaDodSO $O_{4}$, sodium dodecyl sulfate

IA T, hypoxanthine aminopterine thymidine PBS, phosphate-buffered saline

Prolidase (imidodipeptidase, EC 3.4.13.9) splits imidodipeptides with C-terminal proline or hydroxyproline residues. In humans, prolidase activity that is absent or markedly decreased results in prolidase deficiency, a genetic disease transmitted through autosomal recessive inheritance (1). This defect has been associated with mental retardation, imidodipeptiduria, and in some instances, deep skin ulcers (2). It is known that the clinical features of the disease vary from family to family and even within a family (2). In one instance, a man with an absence of prolidase

Received March 9, 1987; accepted July 16, 1987

Reprint requests Fumio Endo. M.D. Department of Pediatrics. Kumamoto University Medical School, Kumamoto 860, Japan

Supported in part by a grant for research from The Ministry of Education. Japan. activity in blood cells had no clinical abnormalities, whereas his brother, who had the same deficiency, had typical clinical features (3).

The properties of prolidase from mammals, including humans. have been reported (4-11). Most of the evidence obtained indicates that prolidase is a ubiquitous enzyme the substrate specificity of which is restricted to imidopeptides $(7,9,10)$. However, the knowledge of human prolidase is limited and an immunological analysis of the human enzyme with a specific antibody has apparently not been reported. The nature of the prolidase mutation is poorly understood.

To begin to address some of these problems, we designed improved method for purifying the enzyme. Using a highly purified preparation, we prepared monoclonal and polyclonal antibodies directed against human prolidase and demonstrated the subunit of prolidase in crude extracts of the liver and erythrocytes. In addition. we noted the absence of the subunit in a patient with prolidase deficiency.

\section{EXPERIMENTAL PROCEDURES}

Materials. Bacterial protein A adsorbent was obtained from Kaketsuken Co. Ltd. (Kumamoto. Japan). CNBr-activated Sepharose $4 \mathrm{~B}$ was purchased from Pharmacia Fine Chemicals (Uppsala, Sweden). (Glycyl-1,-proline was a product of Peptide Research Institute (Osaka, Japan). Affinity purified goat antimouse $\operatorname{IgG}$ was purchased from Jackson Immuno Research Laboratories, Inc. (Avondale), and peroxidase-conjugated swine immunoglobulin to rabbit immunoglobulin was a product of DAKOimmunoglobulins (Glostrup, Denmark).

Purification of prolidase from human liver. Liver tissue obtained at autopsy was kept at $-70^{\circ} \mathrm{C}$ until use. One hundred $\mathrm{g}$ (wet weight) of the liver was homogenized in ice cold $50 \mathrm{mM}$ Tris $\mathrm{HCl}$ buffer, $\mathrm{pH} 7.4$, with a Teflon glass pestle. The supernatant that was obtained by centrifugation at $500 \times g$ for $10 \mathrm{~min}$ and then $15,000 \times g$ for 20 min was fractionated by ammonium sulfate $(40-60 \%)$. The precipitate was suspended in buffer A (made by mixing equal volumes of $20 \mathrm{mM}$ Tris- $\mathrm{HCl}, \mathrm{pH} 7.4$. and $4 \mathrm{mM}$ sodium phosphate buffer, $\mathrm{pH} 7.4$ ) and dialyzed extensively against the same buffer. The dialysate was applied to a hydroxyapatite column $(2.6 \times 50 \mathrm{~cm})$, previously equilibrated with buffer $A$. The column was washed with buffer $A$ and prolidase was eluted with the buffer, as a broad peak. The fraction containing the enzyme was applied to a column of DEAE cellulose $(1.2 \times 5 \mathrm{~cm})$, previously equilibrated with buffer $A$. The column was washed with $50 \mathrm{mM}$ Tris- $\mathrm{HCl}$ buffer $\mathrm{pH} 7.4$, and the prolidase was then eluted by $350 \mathrm{mM}$ Tris- $\mathrm{HCl}$ buffer. $\mathrm{pH}$ 7.4. The fraction containing the enzyme was dialyzed against 
$10 \mathrm{mM}$ Tris- $\mathrm{HCl}$ buffer, $\mathrm{pH} 8.0$, and the dialysate was subjected to ion exchange (Mono Q 5/20, Pharmacia Fine Chemicals) and then to gel filtration (Superose 12, Pharmacia Fine Chemicals), which were run in an HPLC system (Pharmacia Fine Chemicals). The prolidase was eluted from the Mono Q column with a salt gradient from 100 to $500 \mathrm{mM}$ of Tris- $\mathrm{HCl}$ buffer, $\mathrm{pH} 8.0$. The fraction containing the enzyme was fractionated by Superose in $50 \mathrm{mM}$ Tris- $\mathrm{HCl}$ buffer, $\mathrm{pH}$ 8.0. Rechromatography on the Mono Q column usually resulted in two peaks of proteins, the earlier of which possessed prolidase activity. The final preparation is shown in Figure 1.

Purification of prolidase from erythrocytes. When we analyzed the enzyme prepared using a previously described method (9), several protein peaks were seen on the HPLC. We then used the following method: washed erythrocytes (from $200 \mathrm{ml}$ whole blood) were hemolyzed by freezing and thawing, and the hemolysate was centrifuged at $15,000 \times g$ for $10 \mathrm{~min}$. The supernatant was diluted with $50 \mathrm{mM}$ Tris- $\mathrm{HCl}$ (four times) and mixed with DEAE cellulose preequilibrated with $50 \mathrm{mM}$ Tris- $\mathrm{HCl}, \mathrm{pH} 7.4$ (50 g of DE52 for $200 \mathrm{ml}$ whole blood). The mixture was stirred gently for $4 \mathrm{~h}$ at $4^{\circ} \mathrm{C}$, and the residue was packed in a column $(7 \mathrm{~cm}$ in diameter). The column was washed with $50 \mathrm{mM}$ Tris$\mathrm{HCl}$ buffer and the prolidase was eluted with $350 \mathrm{mM}$ Tris- $\mathrm{HCl}$ buffer, $\mathrm{pH}$ 7.4. As described for the liver enzyme, the eluate was subjected to ammonium sulfate fractionation, hydroxyapatite column chromatography $(4 \times 15 \mathrm{~cm}$ for $200 \mathrm{ml}$ whole blood $)$ and HPLC. Similar purification as that for the liver enzyme was obtained by HPLC; however, sometimes closely related proteins caused contamination. In that case even further rechromatographies with low recovery rates were required.

Production of monoclonal antibody. Highly purified liver prolidase was used to immunize a BALB/c female mouse by intraperitoneal administration of about $25 \mu \mathrm{g}$ protein emulsified in Freund's complete adjuvant (Difco Laboratories, Detroit, MI). The mouse was reimmunized 2 wk later with $25 \mu \mathrm{g}$ of protein given intravenously, and 3 days later the spleen was removed. Spleen cells $\left(1 \times 10^{8}\right)$ and P3U- 1 myeloma cells $\left(5 \times 10^{7}\right)$ were fused in the presence of polythylene glycol (12) ( $\mathrm{MW}=4000$; Sigma Co. Ltd., St. Louis, MO). The fused cells were incubated with HAT medium for 10 days in a $\mathrm{CO}_{2}$ incubator and then

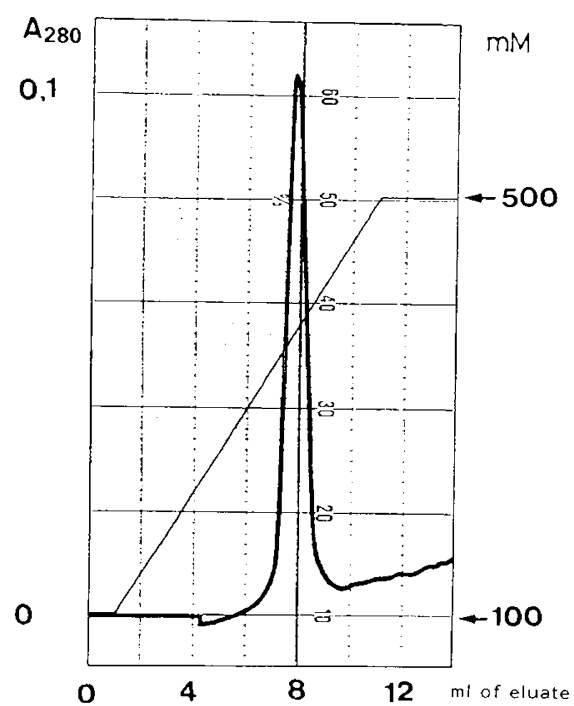

Fig. 1. Elution profile of highly purified prolidase from liver on HPLC (Mono Q column) is shown. The solid curve represents absorbance at $280 \mathrm{~nm}$ and the solid line indicates the salt gradient produced by gradient programmer GP-200 (Pharmacia Fine Chemicals). The gradient started at $100 \mathrm{mM}$ Tris- $\mathrm{HCl}$ buffer, $\mathrm{pH} 8.0$, and ended at $500 \mathrm{mM}$ of the same buffer. The column was washed with $5 \mathrm{ml}$ of $10 \mathrm{mM}$ Tris- $\mathrm{HCl}$ buffer prior to start of the gradient. Flow rate was $1 \mathrm{ml} / \mathrm{min}$. Enzyme activity existed with the peak. replaced in hypoxanthine thymidine medium. The clones were tested for the production of antibody to human liver prolidase as follows. The wells of a polyvinyl microplate (96-well immunoplate, Nunc) were coated with antimouse $\operatorname{IgG}(5 \mu \mathrm{g} / \mathrm{ml}$ in 0.1 $\mathrm{M}$ carbonate buffer, $\mathrm{pH} 8.5$ ) and left overnight at $4^{\circ} \mathrm{C}$. After washing the wells three times with $10 \mathrm{mM}$ sodium phosphate buffer, pH 7.4, containing $150 \mathrm{mM} \mathrm{NaCl}$ (PBS), $50 \mu \mathrm{l}$ of the culture supernatant was added and the mixture then incubated at $37^{\circ} \mathrm{C}$ for $2 \mathrm{~h}$. The supernatant was removed and after three washings with PBS, $100 \mu \mathrm{l}$ of a solution containing approximately $30 \mathrm{mU}$ of prolidase was added. The solution was prepared as follows: human liver obtained at autopsy was homogenized in a 10 -fold volume of $50 \mathrm{mM}$ Tris- $\mathrm{HCl}$ buffer, $\mathrm{pH} 7.4$. The homogenate was centrifuged at $15,000 \times g$ for $20 \mathrm{~min}$, the supernatant was mixed with $5 \%$ bovine serum albumin in PBS, and the enzyme activity was adjusted to $30 \mathrm{mU} / \mathrm{ml}$. Incubation was continued for $2 \mathrm{~h}$ at $37^{\circ} \mathrm{C}$ or overnight at $4^{\circ} \mathrm{C}$. The solution was then removed and the wells were washed three times with PBS. This was followed by incubation with $100 \mu \mathrm{l}$ of $2 \mathrm{mM}$ glycyl-Lproline in $50 \mathrm{mM}$ Tris- $\mathrm{HCl}$ buffer, $\mathrm{pH} 7.4$, containing $5 \mathrm{mM}$ $\mathrm{MnCl}_{2}$. Incubation was carried for $4 \mathrm{~h}$ at $37^{\circ} \mathrm{C}$, and at the end of incubation $100 \mu \mathrm{l}$ of acid ninhydrin solution prepared according to the description of Chinard were added. The plate was heated at $90-95^{\circ} \mathrm{C}$ for $15 \mathrm{~min}$ to determine the amount of $\mathrm{L}-$ proline released from glycyl-L-proline, after which the absorbance at $495 \mathrm{~nm}$ was recorded.

Controls for nonspecific binding were included by omitting either the goat antimouse $\mathrm{IgG}$ or the culture supernatant. Less than 0.01 of absorbance was recorded under these conditions. Several clones gave strongly positive responses with optical densities above 0.2 . These responses suggested that the culture supernatants included antibody to human liver prolidase. The cloned plaques which gave a positive response were selected and recloned several times in hypoxanthine thymidine medium by limiting dilution (14). Finally, the cell line used in the present study was established. The immunoglobulin (designated EP-2) produced by this clone was found to be of the immunoglobulin subclass $\operatorname{Ig} G_{1}$. The hybridoma cells were grown as an ascites form by intraperitoneal injection into pristane-treated mice (14) and the resulting ascites fluid was used as a source of monoclonal antibody after removal of cells by centrifugation at $1000 \times g$ for $10 \mathrm{~min}$. The IgG was purified from the ascites fluid by ammonium sulfate precipitation and ion exchange column (Mono Q column) equipped with an HPLC system (Pharmacia).

Preparation of antiserum. Antiserum was produced in a rabbit by injections of protein in Freund's adjuvant (Difco). The injection schedule was as follows: $100 \mu \mathrm{g}$ of human erythrocyte prolidase was injected into the lymphnodes of the hind limbs (15), followed by $100 \mu \mathrm{g}$ subcutaneous booster injections at 2wk intervals. The antiserum was used for further experiments without any treatment. A single precipitation line was seen on Ochterony's plate, when the antiserum was analyzed with purified erythrocyte enzyme.

Preparation of immobilized IgG (EP-2). Purified IgG (EP-2) as described above was extensively dialyzed against $0.1 \mathrm{M}$ sodium phosphate buffer, pH 7.4 containing $0.5 \mathrm{M} \mathrm{NaCl}$. CNBr-activated Sepharose 4B was reconstituted and washed according to the manufacturer's instructions. It was then coupled with the EP-2 antibody through overnight incubation at $4^{\circ} \mathrm{C}$ with the antibody $(0.3 \mathrm{mg}$ of protein $/ \mathrm{ml}$ of gel) in $0.1 \mathrm{M}$ sodium phosphate buffer, $\mathrm{pH} 7.4$, containing $0.5 \mathrm{M} \mathrm{NaCl}$. Approximately $95 \%$ of the antibody was coupled to the Sepharose.

Affinity purification of prolidase from crude extracts. Postmortem specimens of liver, kidney, small intestine, and blood from control subjects with normal prolidase activity were used. Screening for variant forms of prolidase (16) had not previously been done. Tissues were routinely homogenized $(0.1 \mathrm{~g}$ wet weight per $\mathrm{ml})$ in $50 \mathrm{mM}$ Tris- $\mathrm{HCl}$ buffer, pH 7.4 phenylmethyl sulfonyl fluoride $(1 \mathrm{mM})$, benzamidine hydrochloride $(2 \mathrm{mM})$, using a glass Teflon homogenizer. The homogenates were centrifuged at 
$500 \times g$ for $10 \mathrm{~min}$ and the supernatants at $15,000 \times g$ for 20 min. The resulting supernatants were mixed with appropriate amounts of suspension of EP-2 immobilized Sepharose 4B (20$40 \mu \mathrm{lgel})$. The mixtures $(0.5-3 \mathrm{ml})$ were incubated at room temperature for $2 \mathrm{~h}$ or at $4^{\circ} \mathrm{C}$ for $6 \mathrm{~h}$. After incubation, the gel was precipitated by brief centrifugation and washed three times with $1.5 \mathrm{ml}$ ice cold $50 \mathrm{mM}$ Tris- $\mathrm{HCl}$ buffer, $\mathrm{pH} \mathrm{7.4}$. The final gel precipitate was mixed with $150 \mu \mathrm{l} 62.5 \mathrm{mM}$ Tris $\mathrm{HCl}$ buffer. pH 6.8, containing 4\% NaDodSO $4,4 \%$ mercaptoethanol, and $10 \%$ glycerol. The resulting suspensions were boiled at $100^{\circ} \mathrm{C}$ for $1 \mathrm{~min}$. After precipitation of the gel, $100 \mu \mathrm{l}$ of supernatant was used for gel electrophoresis.

Erythrocytes were separated from whole blood by centrifugation and washed three times with ice cold $150 \mathrm{mM} \mathrm{NaCl}$. The crude hemolysate was prepared by freezing and thawing the packed erythrocytes. The supernatant of the crude hemolysate after centrifugation at $15,000 \times g$ for $5 \mathrm{~min}$ was used as a crude extract. Affinity purification of prolidase from the erythrocytes was carried out as described above.

Immunoprecipitation studies. Crude tissue extracts were incubated for $2 \mathrm{~h}$ at $24^{\circ} \mathrm{C}$ with the monoclonal antibody or antiserum, followed by Staphylococcus aureus $\left(24^{\circ} \mathrm{C}, 1 \mathrm{~h}\right)$. The insolubilized immune complexes were precipitated by centrifugation at $15,000 \times g$ for $5 \mathrm{~min}$, after which prolidase activities in the supernatants were measured.

Electrophoresis and immunoblotting. Polyacrylamide gel electrophoresis in the presence of $\mathrm{NaDodSO}_{4}$ was performed using the discontinuous buffer system of Laemmli (17) with $5 \%$ acrylamide for stacking gel and $10 \%$ acrylamide for separating gel. The molecular weight markers used were myosine $(\mathrm{MW}=$ $200,000), \beta$-galactosidase $(\mathrm{MW}=116,000)$, phosphorylase $\mathrm{b}$ $(\mathrm{MW}=92,500)$, bovine serum albumin $(\mathrm{MW}=67,000)$. ovo albumin $(\mathrm{MW}=43,000)$, carbonic anhydrase $(\mathrm{MW}=31.000)$, and soybean trypsin inhibitor $(\mathrm{MW}=21,500)$. For immunoblotting, proteins were transferred to nitrocellulose (18). The nitrocellulose was incubated with the antiserum (1:100 dilution) and then peroxidase-conjugated antirabbit immunoglobulins. The peroxidase was visualized by 4-methyl-1-naphthol (Aldrich Chemical Company, Inc., Milwaukee, WI).

Gel filtration column chromatography for molecular mass estimation. For estimation of molecular mass of prolidase on gel filtration, the Superose column was calibrated according the a b

Fig. 2. Coomasie staining of the $\mathrm{NaDOdSO}_{4} /$ acrylamide gel. The

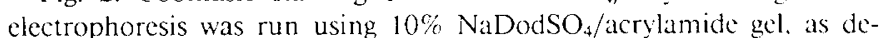
scribed in "Experimental procedures." The gel was stained with coomasie brilliant blue R-250 and destained. L.ane a, highly purified preparation from liver $(15 \mu \mathrm{g})$. Lane $b$, highly purified preparation from erythrocytes $(15 \mu \mathrm{g})$.

\begin{tabular}{|c|c|c|c|c|c|}
\hline & $\begin{array}{l}\text { Volume } \\
(\mathrm{ml})\end{array}$ & $\begin{array}{l}\text { Total protein } \\
(\mathrm{mg})\end{array}$ & $\begin{array}{l}\text { Total activity } \\
\text { (U) }\end{array}$ & $\begin{array}{l}\text { Specific activity } \\
\quad(\mathrm{U} / \mathrm{mg})\end{array}$ & $\begin{array}{c}\text { Recovery } \\
(\%)\end{array}$ \\
\hline Crude extract & 520 & 8700 & 443.7 & 0.051 & 100 \\
\hline $\begin{array}{l}\text { Ammonium sulfate fractiona- } \\
\text { tion }\end{array}$ & 33 & 3900 & 370.5 & 0.095 & 83.5 \\
\hline $\begin{array}{l}\text { Hydroxylapatite and DEAE } \\
\text { cellulose }\end{array}$ & 23 & 42.7 & 163.8 & 3.9 & 36.9 \\
\hline Mono Q (first) & 1.0 & $4.1^{*}$ & 52.7 & 12.8 & 11.9 \\
\hline Superose 12 & 2.0 & $0.31^{*}$ & 21.3 & 71 & 4.8 \\
\hline Mono Q (second) & 0.5 & $0.075^{*}$ & 12.5 & 167 & 2.8 \\
\hline
\end{tabular}

* Amounts of protein were estimated by the absorbance at $280 \mathrm{~nm}$.

Table 2. Purification of prolidase from human ervthrocltes

Crude hemolysate

DE 52 and ammonium sulfate fractionation

Hydroxylapatite and DE 52

Mono Q (first)

Superose 12

Mono Q (second)

$\begin{array}{ccc}\begin{array}{c}\text { Volume } \\ (\mathrm{ml})\end{array} & \begin{array}{c}\text { Total protein } \\ (\mathrm{mg})\end{array} & \begin{array}{c}\text { Total activity } \\ (\mathrm{U})\end{array} \\ 450 & 20100 & 422.1 \\ 18 & 557 & 299.6 \\ 12 & & \\ 1.0 & 25 & 101.3 \\ 2.0 & 2.8^{*} & 38.2 \\ 0.5 & 0.24^{*} & 12.2 \\ & 0.05^{*} & 8.6\end{array}$

$\begin{array}{cc}\begin{array}{c}\text { Specific activity } \\ (\mathrm{U} / \mathrm{mg})\end{array} & \begin{array}{c}\text { Recovery } \\ (\%)\end{array} \\ 0.021 & 100 \\ 0.54 & 71 \\ 4.05 & 24 \\ 13.6 & 9.0 \\ 5.08 & 2.9 \\ 171 & 2.0\end{array}$

* Amounts of protein were estimated by the absorbance at $280 \mathrm{~nm}$. 


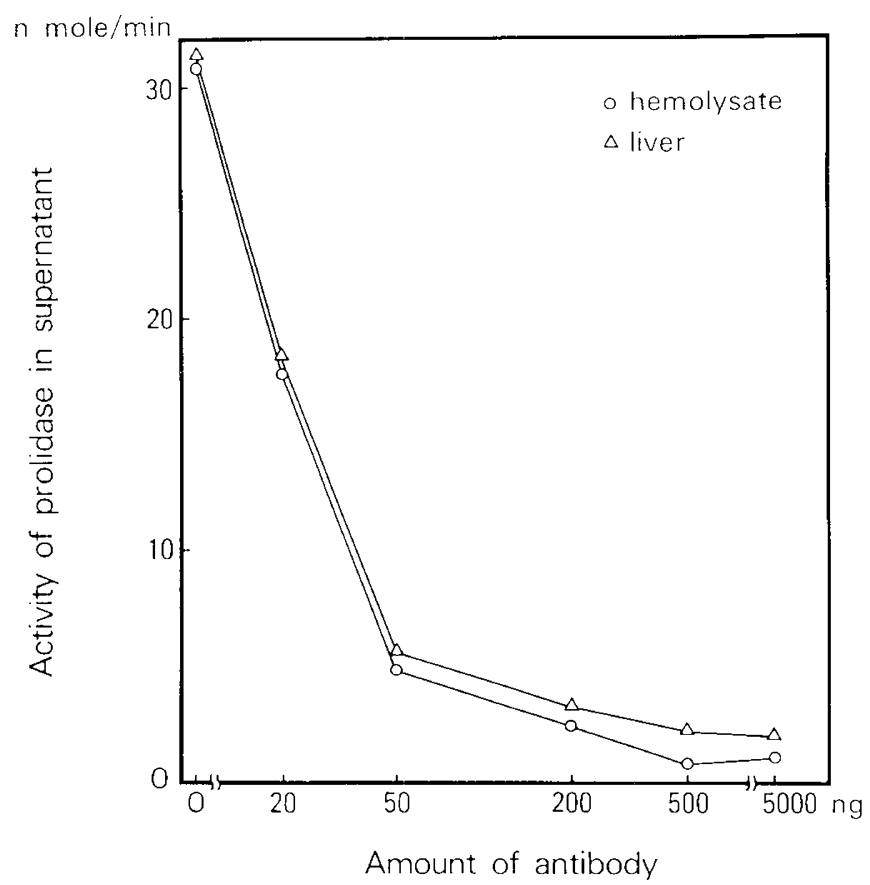

Fig. 3. Immunoprecipitation of prolidase by monoclonal antibody EP-2. The purified antibody was mixed with crude extracts which contained approximately $30 \mathrm{mU}$ of prolidase activities in a total volume of $1.0 \mathrm{ml}$. Two hundred $\mu \mathrm{l}$ of a suspension of $S$. aureus was added before the centrifugation (details in "Experimental procedures).

following materials: blue dextran 2000, catalase (MW = $232,000)$, aldolase $(\mathrm{MW}=158,000)$, bovine serum albumin $(\mathrm{MW}=67,000)$, and ovalbumin $(\mathrm{MW}=43,000)$. The chroma-

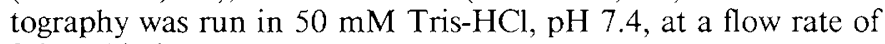
$0.25 \mathrm{ml} / \mathrm{min}$.

Other assays. Prolidase activity was measured using glycyl-Lproline as a substrate in $50 \mathrm{mM}$ Tris- $\mathrm{HCl}$ buffer, $\mathrm{pH} 7.4$ containing $10 \mathrm{mM} \mathrm{MnCl}$. The assay mixture was preincubated at $37^{\circ} \mathrm{C}$ for $30-60 \mathrm{~min}$ in a total volume of 200 and $50 \mu \mathrm{l}$ of 0.1 $\mathrm{M}$ glycyl-L-proline was added to initiate the reaction. The reaction was terminated by adding $250 \mu \mathrm{l}$ of $10 \%$ trichloroacetic acid, and the supernatant obtained after centrifugation was measured for proline by the method of Chinard (13) as described previously (19) $(1 \mathrm{U}=1 \mu \mathrm{mol} / \mathrm{min}$ proline liberated from glycylL-proline). Amounts of protein were estimated by the method of Lowry et al. (20) using bovine serum albumin as standard or by absorbance at $280 \mathrm{~nm}$.

\section{RESULTS}

Highly purified preparations, which were chromatographically pure on the ion exchange column (Fig. 1) and gel filtration column of HPLC, were obtained. The purifications of prolidase from liver and erythrocytes are summarized in Tables 1 and 2, respectively. The recovery rate of prolidase was very low; perhaps partially due to the progressive decrease of specific activity of the enzyme, since repeated chromatography on HPLC sometimes results in a decrease of specific activity. The two enzymes from liver and erythrocytes could not be distinguished on HPLC with the ion exchange column and the gel filtration column. In $\mathrm{NaDodSO}_{4} /$ acrylamide gel electrophoresis, the highly purified preparations from liver and erythrocytes contained a major protein with $\mathrm{MW}=56,000$ and a minor one of $\mathrm{MW}=43,000$ (Fig. 2). The relative molecular mass of prolidase was estimated on a gel filtration as $\mathrm{MW}=97,000$, for both enzyme preparations. These preparations were used for immunization of mice and rabbits, as described.

The ability of the monoclonal antibody to immunoprecipitate a

b

\section{$\mathrm{Mr}$}

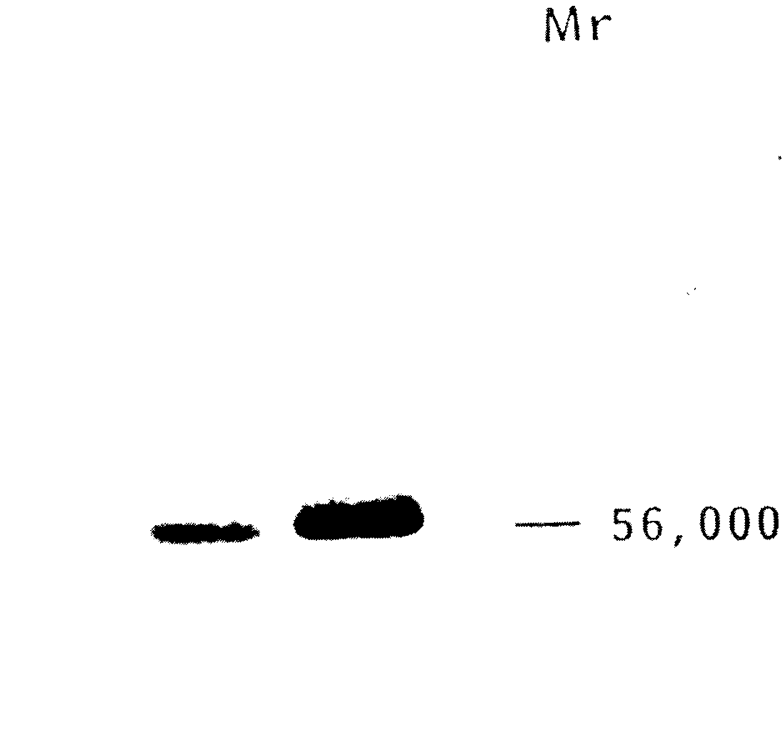

Fig. 4. Immunoblotting analysis of affinity purified prolidase from liver and erythrocytes. The crude tissue extracts prepared from $0.1 \mathrm{~g}$ wet weight of tissues or $0.1 \mathrm{ml}$ packed erythrocytes were used as starting materials (details in "Experimental procedures"). The reducing condition was prepared with $10 \mathrm{mM}$ dithiotreitol in the sample buffer. Affinity purified, liver (lane $a$ ) and erythrocytes (lane $b$ ) were analyzed on $\mathrm{NadoDSO}_{4} /$ acrylamide gel and immunoblotting with the antiserum as described in "Experiment procedures."

prolidase was tested using $S$. aureus coated with protein A. Precipitation was measured by monitoring enzyme activity in the supernatant solution. As shown in Figure 3, the antibody bound to prolidase from the erythrocytes and liver. Results of control experiments included the following: 1) prolidase activities were not precipitated with $S$. aureus in the absence of the mouse IgG-EP2, 2) prolidase activities were not precipitated with nonspecific mouse $\operatorname{IgG}$ and $S$. aureus. Prolidase activities in these tissue and cell extracts were not inhibited by EP-2, under the conditions described. Similar titration curves for different tissue extracts indicated that this antibody recognized equally prolidase from the liver and erythrocytes. This suggested to us that the prolidase in these tissues and cells has the same antigenicity against EP-2 and that all of the prolidase activities were associated with the antigen. When we used antiserum for immunoprecipitation, similar titration curves for liver and erythrocytes were obtained (data not shown).

To assess whether human erythrocyte prolidase from clinically normal individuals could be recognized by the antibody, numbers of peripheral blood samples were tested. In these experiments, antibody (EP-2)-coated immunoplates were used. In more than 400 blood samples analyzed, there were no cases in which 

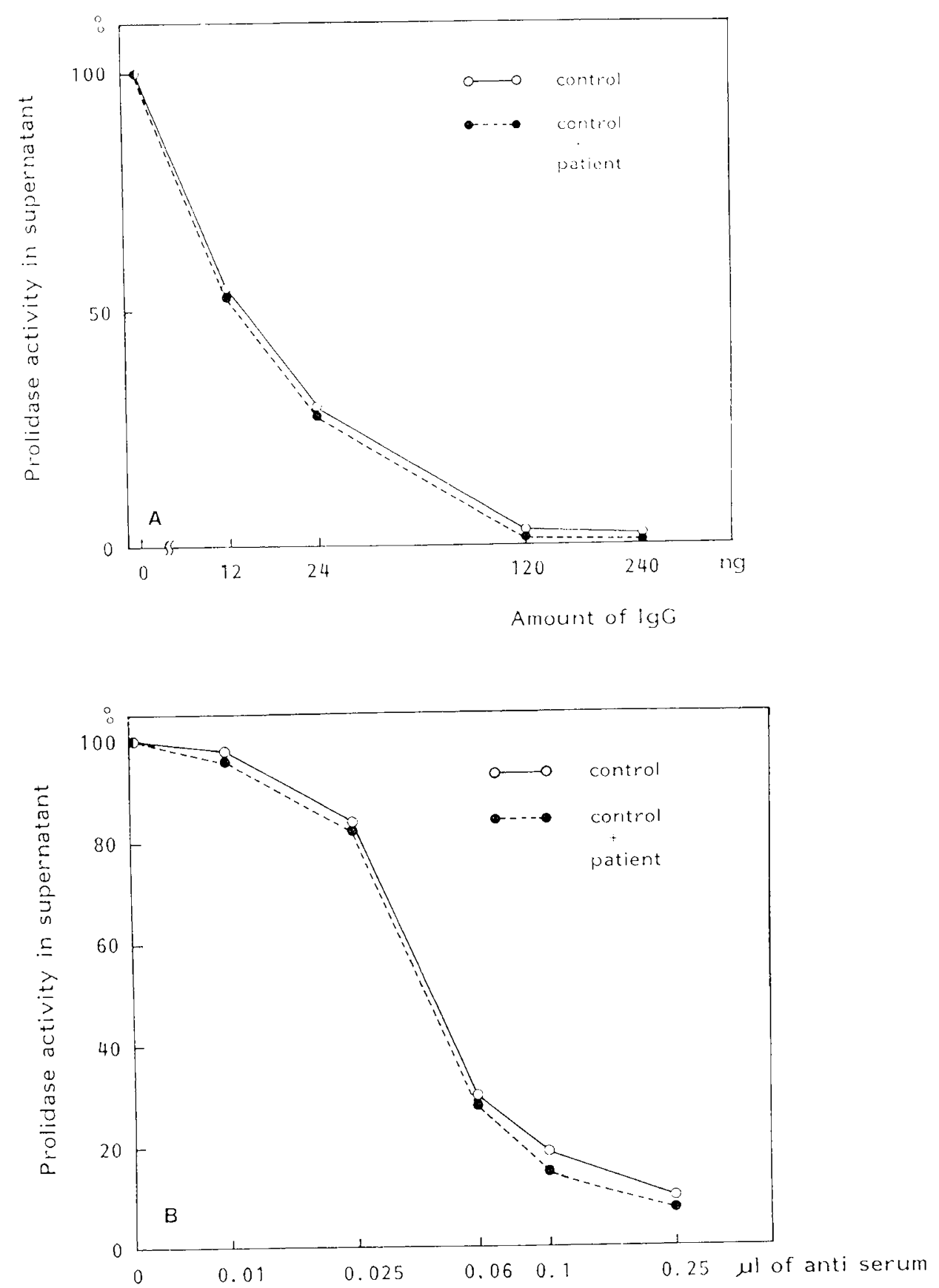

Fig. 5. Immunoprecipitation of erythrocyte prolidase by F.P-2 and antiserum in the presence or absence of the same fraction from a patient with prolidase deficiency. (rude extract from $10 \mu \mathrm{l}$ of packed erythrocytes was incubated with various amounts of $\mathrm{kP}-2(1)$ and antiserum $(B)$ in the presence or absence of the same fraction (100 $\mu$ of packed erythrocytes) from a patient with prolidase deficiency. The totat volume of the mixture was 200 and $100 \mu$ lof S. alure'us suspension was added before centrifugation (details in "Experimental procedures").

the enzyme did not bind to the antibody. It is therefore likely that most prolidase in normal individuals is recognized by the antibody.

We therefore immobilized the antibody to Sepharose $4 \mathrm{~B}$ and the resulting immunoadsorbent was tested for its ability to bind prolidase. The purified prolidase from the liver and erythrocytes as well as prolidase in the crude extracts of liver and erythrocytes bound to the immunoadsorbent. Thus, this immunoaffinity gel can be used to concentrate the enryme from crude tissue extracts. Several batches of immobilized antibody were prepared and immunoprecipitation studies with these immunoadsorbents demonstrated that $1 \mathrm{mg}$ of immobilized antibody could bind to $25-40 \mu \mathrm{g}$ protein of highly purified preparation from the erythrocytes.
Results of immunoblotting after . ValodSOA/acrylamide get electrophoresis of affinity purified materials are shown in Figure 4. Affinity purification had been used to enrich prolidase. specifically from crude tissue extracts. Approximately 11 I prolidase bound to $1 \mathrm{mlgel}$ in this experiment. $A$ protein of $\mathrm{MW}=56,000)$ was stained when affinity purified materials from liver and erythrocytes were analyzed (Fig. 4). Control experiments showed that the immunobloting was indeed specitic. 1) The $\mathrm{MW}=$ $56.000)$ protein was not visualized when the monoctonal antibody. was analyed. 2) Control experiments with a get made in a same manner using non specific mouse IgCi did not demonstrate the protein. 3) The protein was not evident when the supernatant of the immunoprecipitation experiment was analyzed. The $\mathrm{MW}=$ $4.3 .(0)()$ protein was visualized in some experiments with pro- 
longed incubation of EP-2 Sepharose and sample in the absence of proteinase inhibitors. It is possible that the $\mathrm{MW}=43,000$ protein, which is found in the highly purified preparations, is a proteolytic product of the $M W=56,000$ protein. However, our experiments did not exclude the possibility that the $\mathrm{MW}=$ 43,000 protein is an unrelated protein. It was suggested that MW $=56,000$ protein was a subunit of prolidase in the erythrocytes and in the liver.

To study whether immunologically cross-reactive material was included in the hemolysate from a prolidase-deficient patient (prolidase activity was not detected in hemolysate), competition experiments were carried out in which prolidase from $10 \mu \mathrm{l}$ of packed erythrocytes were immunoprecipitated in the presence or absence of $100 \mu \mathrm{l}$ of the same fraction from the patient's peripheral blood. Immunoprecipitations of prolidase from the control by EP-2 and antiserum were not inhibited when the hemolysate from the patient was included in the immunoprecipitation mixtures (Fig. 5, $A$ and $B$ ). These results suggested the absence of immunologically cross-reactive material in the hemolysate from the patient.

The crude extract from the erythrocytes of a prolidase deficient-patient did not yield any positively stained band when analyzed by immunoblotting (Fig. 6). Erythrocytes of five healthy

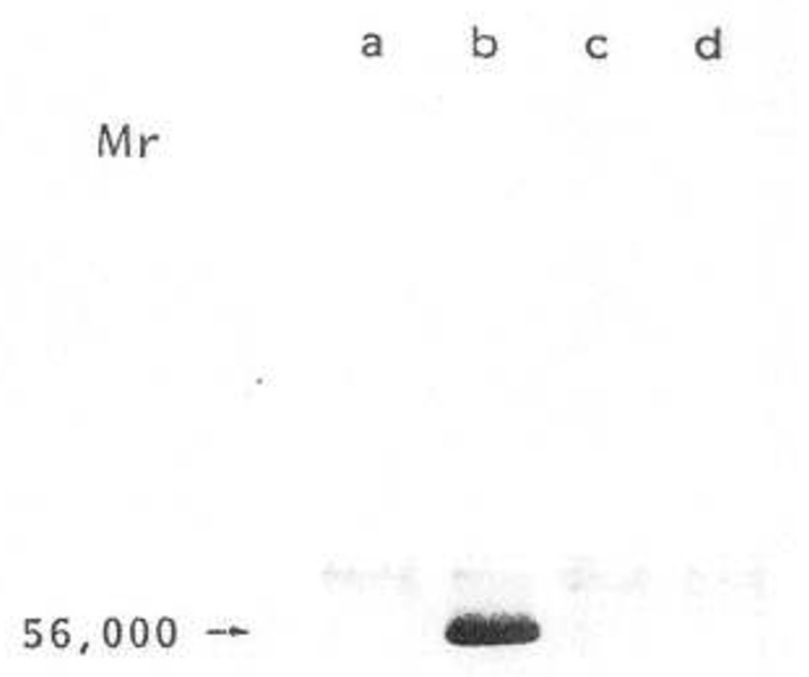

Fig. 6. Immunoblotting analysis of affinity purified prolidase from hemolysates of control and prolidase-deficient subjects. The samples were prepared and analyzed as described in "Experimental procedures". For each lane, $30 \mathrm{mg}$ protein was used as a starting material. Immunoblotting was performed with the antiserum. Lane $a$, crude extract from a patient's erythrocytes was treated with EP-2 Sepharose; lane b, control sample was treated with EP-2 Sepharose; lane c, crude extract from a patient's erythrocytes was treated with nonspecific mouse IgG Sepharose; lane $d$, control sample was treated with nonspecific mouse IgG Sepharose (see "Experimental procedures"). controls studied under identical conditions demonstrated a protein band of $\mathrm{MW}=56,000$. We tentatively conclude that the protein of $\mathrm{MW}=56,000$ was a subunit of erythrocyte prolidase and that this subunit was absent in the erythrocytes of the patient with prolidase deficiency.

\section{DISCUSSION}

This may be the first report concerning an immunochemical analysis of prolidase and prolidase deficiency. Although purification studies of prolidase in porcine (7) and bovine (10) intestine have been described, the knowledge of human prolidase is limited and apparently the only purification study published has been our earlier report (9). To understand this enzyme and its deficiency more accurately, we attempted to identify the protein using a highly specific technique. For this purpose, we developed a monoclonal-monospecific antibody directed against human prolidase. Our results in this regard are clear-cut. Based on our results using the antibody EP-2 to purify the enzyme from crude extracts of tissues and cells, and specific antiserum to identify the enzyme protein in immunoblotting, it is apparent that the protein of $\mathrm{MW}=56,000$ is a subunit of prolidase in liver and erythrocytes. Our immunochemical analysis of hemolysate from a patient with prolidase deficiency indicates that the absence of prolidase activity is accompanied by absence of the $\mathrm{MW}=56,000$ protein. The relative molecular mass of purified enzyme from liver and erythrocytes was estimated to be 97,000 on the gel filtration. Prolidase may be a dimer of $\mathrm{MW}=56,000$ subunit. The relative molecular mass of human prolidase is similar to that of bovine intestine enzyme (10), which exists as a dimer. The mass of the subunit of the human enzyme was coincided with that of the bovine enzyme (10).

We demonstrated that prolidase in the liver and in the erythrocytes could not be distinguished by immunochemical analysis. Clinical observations on patients with prolidase deficiency suggest that the enzyme deficiency involves many organs $(2,21)$, and one can assume that the structural gene for prolidase is identical in many organs.

Our initial interest in developing these studies was in identifying factors that could be involved in the expression of prolidase deficiency. In this regard, our experiments clearly indicate that a defect in the subunit of prolidase is a cause of prolidase deficiency. Further immunochemical analysis of prolidase in prolidase-deficient patients with various degrees of residual activity has to be done. Clinical features of the disorder are not always related to the degree of enzyme deficiency, and genetic heterogeneity of prolidase deficiency may be demonstrable by the immunochemical analysis. Another aspect of this study is providing useful antibodies for further understanding of prolidase and its genetics. This monoclonal antibody can be used for rapid purification of human prolidase.

Acknowledgments. The authors thank M. Ohara for critical comments on the manuscript, Dr. S. Kawamoto for helpful discussions, and $\mathrm{M}$. Hongo and $\mathrm{Y}$. Umeda for secretarial services.

\section{REFERENCES}

1. Mckusick VA 1983 Mendelian Inheritance in Man. The Johns Hopkins University Press, Baltimore

2. Scriver RC, Smith RJ, Phang JM. 1983 Stanbury JB, Wyngaarden JB, Fredrickson DS, Goldstein JL, Brown MS (eds) Disorders of proline and hydroxyproline metabolism. In: The Metabolic Basis of Inherited Disease. McGraw Hill, New York, pp 360-381

3. Isemura M, Hanyu T, Gejyo F, Nakazawa R, Igarashi R, Matsuo S, Ikeda K, Sato Y 1979 Prolidase deficiency with iminodipeptiduria. A familial case with and without clinical symptoms. Clin Chim Acta 93:401-407

4. Bergmann M, Fruton JS 1937 On proteolytic enzymes. XII. regarding the specificity of aminopeptidase and carboxypeptidase. A new type of enzyme in the intestinal tract. J Biol Chem 117:189-202

5. Adams E, Smith EL 1952 Peptidase of erythrocytes. II. Isolation and properties of prolidase. J Biol Chem 198:671-682

6. Davis NC, Smith EL 1956 Purification and some properties of prolidase of 


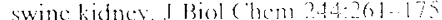

Siostrom 11. Voren () $19 \%$ Seructural propertics of pie intestinal poline

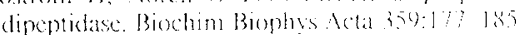

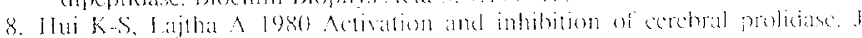
Neurochem $35: 489$. d9.4

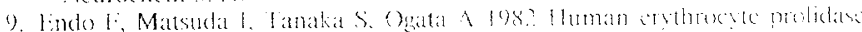
and prolidase deficioney. P'ediatr Res 16:2\%\% 231

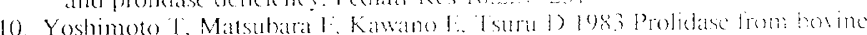

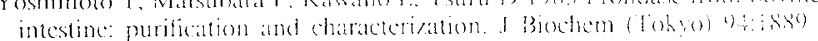
1896

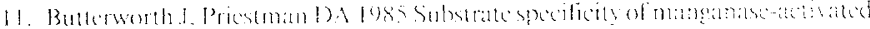

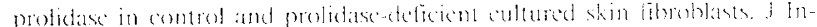
herited Metab 1)is $5: 19 ; 197$

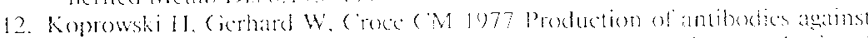
influenza virus by somatic coll hybrists between mouse myclema and primes

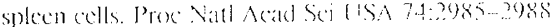

13. (hinard JP 1952 Photometric estimation of proline and ornithine I Biol ( hem $196 \cdot 265 \cdot \ldots 275$

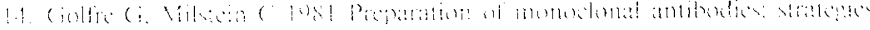
and mand

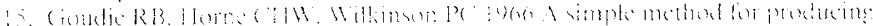

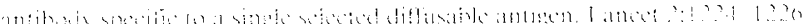

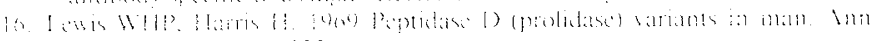

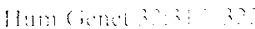

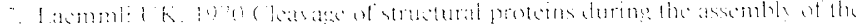

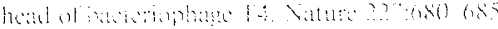

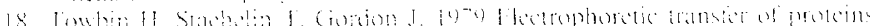

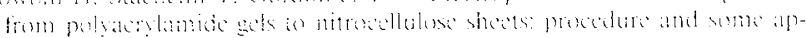

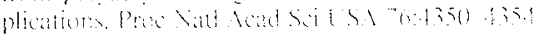

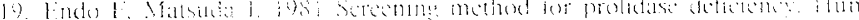
$($ i

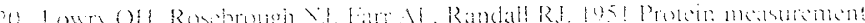

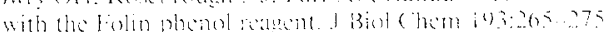

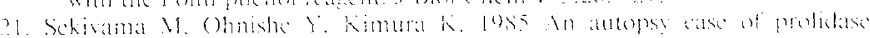

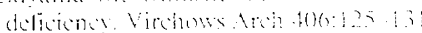

\section{Announcement 1988 Annual Necting Abstract Deadline}

The American Pediatric Society and the Societs for Pediatric Rescarch announce the abstract deadline los the

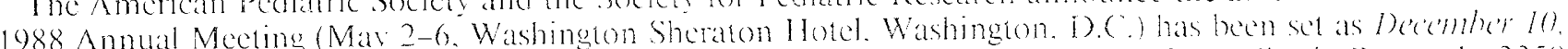

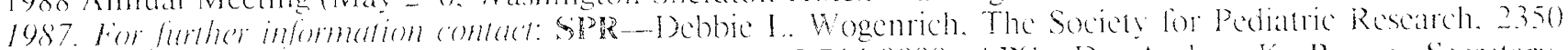

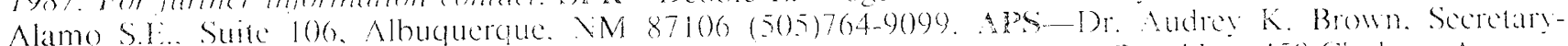

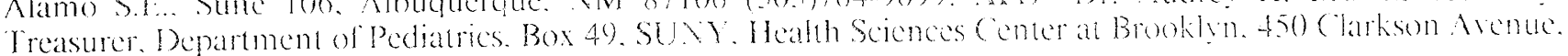
Brooklyn, NY I I203(718)27()-1692. 